\title{
Recurring Issues in Indian Gaming Compact Approval
}

\author{
Kevin K. Washburn
}

$\mathbf{T}$ HE INDIAN GAMING LANDSCAPE has developed in unexpected ways in the past thirty years. One development is the robust relationship between tribal governments and state governments that was spawned by the Indian Gaming Regulatory Act $(\text { IGRA })^{1}$ and its requirement for tribal-state compacts for Class III gaming. ${ }^{2}$ Few could have anticipated the development of such rich relationships, in which tribes regularly negotiate with states and sometimes wield tremendous power in state capitols. In some states, the governor has authority to negotiate and sign compacts. ${ }^{3}$ In others, the governor may have the authority only to negotiate, but ratification must occur through the state legislative process. ${ }^{4}$ And there are other variations as well. ${ }^{5}$

Achieving agreement between a state and a tribe, and then achieving ratification of that agreement through state and tribal legislative processes, are challenging endeavors. In part because of these challenges and the increasing complexity and sophistication of the negotiations between tribes and states, the parties negotiating gaming compacts sometimes lose sight of an important legal requirement, namely, federal review of the final tribal-state compact at the Department of the Interior ("Department" or "Interior").

Kevin Washburn is a professor of law at the University of New Mexico School of Law in Albuquerque, New Mexico. He is a former assistant secretary for Indian Affairs at the U.S. Department of the Interior, and a former general counsel of the National Indian Gaming Commission (NIGC). He is the author of a law school casebook, entitled Gaming/Gambling LAW (Aspen Wolters Kluwer 2011), and numerous articles. Professor Washburn has also served as a consultant or expert witness in matters of gaming regulation, judicial and administrative litigation, and arbitration. He is solely responsible for the views and errors herein, but he has learned from years of guidance and collaboration with colleagues at Interior and the NIGC.

(C) Keven K. Washburn, 2016; Published by Mary Ann Liebert, Inc. This Open Access article is distributed under the terms of the Creative Commons Attribution Noncommercial License (http:// creativecommons.org/licenses/by-nc/4.0/) which permits any noncommercial use, distribution, and reproduction in any medium, provided the original author(s) and the source are credited.
Failing to account for the need for federal approval can undermine the entire negotiation process. Since 1998, the Department has disapproved at least 20 compacts. A disapproval can be disastrous, undermining months or years of negotiation and, at a minimum, returning the parties to the negotiation table. The purpose of this article is to highlight several recurring problem areas that can place compact approval at risk. These include the requirement in IGRA that a compact avoid issues that are not germane to gaming, that the compact avoid regulating Class II gaming, which is beyond state authority, and the requirement that the state avoid expanding its reach over ancillary services and spaces that are not used for gaming.

\section{EXPLANATION OF THE PROBLEM}

A recent example is the compact between the Mashpee Wampanoag Tribe of Massachusetts and the Commonwealth of Massachusetts. After months of negotiation, ${ }^{6}$ the Mashpee Tribe and the governor of Massachusetts reached a deal that was ratified by the state legislature on July 26, 2012, and then signed by the governor and the tribe on July 30 , 2012 . $^{7}$ After celebration of the culmination of the

${ }^{1}$ Pub. L. No. 100-497, 102 Stat. 2467-2486 (Oct. 17, 1988), codified at 25 U.S.C. $\$ \S 2710-2721$ (hereinafter IGRA).

${ }^{2}$ Kevin K. Washburn, Federal Law, State Policy, and Indian Gaming, 4 Nev. L.J. 285 (2003-2004).

${ }^{3}$ See, e.g., Wisc. STAT. ANN. § 14.035 (2015).

${ }^{4}$ See, e.g., CAL. Gov't Code $\S 12012.25(\mathrm{~d})$ (2015).

${ }^{5}$ See generally Kevin K. Washburn, Recurring Problems in Indian Gaming, 1 Wyo. L. REv. 427 (2001).

${ }^{6}$ Gale C. Toensing, Massachusetts Governor Signs Mashpee Gaming Compact, Indian Country Today Media Network (July 31, 2012), <http://indiancountrytodaymedianetwork.com/ 2012/07/31/massachusets-governor-signs-mashpee-gamingcompact-126809>.

${ }^{7}$ Mark Arsenault, State's Take May Doom Casino Deal, BosTON GLOBE, July 29, 2012, <https://www.bostonglobe.com/ metro/2012/07/28/mashpee-wampanoag-tribal-compact-maytoo-generous-state-risking-federal-rejection/e4aeZgSkOIuhM7M hcI5Z1L/story.html>. 
deal, the compact was sent to Interior, where it was disapproved less than two and a half months later. ${ }^{8}$ The October 2012 disapproval sent the parties back to the negotiation table, and it took more than a year for the compact to be renegotiated, ratified by the legislature, and returned to the Department for review. The new compact was approved in January of 2014. ${ }^{9}$ While the Mashpee compact episode ultimately had a happy ending, the disapproval caused uncertainty for more than 14 months.

In the world of Indian gaming, even a mere delay can have profoundly negative effects. Investors in a casino development may get frustrated and walk away, causing finance options for the tribe to change dramatically. State and tribal political leadership can change, disrupting the course of negotiations and the level of commitment to a gaming initiative. Market conditions can change. In routine compact negotiations, millions of dollars in gaming revenue for tribes and revenue-sharing for state governments hang in the balance. It is in the interest of both the state and the tribe to avoid a disapproval.

Federal officials have worried for years that federal interests are not adequately considered in the compact negotiation process. In 2002, then-Secretary Gale Norton complained that "the Department receives a compact that is a fait accompli without much opportunity for the Department to express its policy views[.]" ${ }^{10}$ Understanding of the issues at play in federal review can be gleaned from hundreds of compact review letters and those issues have evolved over time.

The first compacts approved by the Department were negotiated in 1989 and approved in 1990 between the State of Minnesota and Sioux tribes and Ojibwe bands. ${ }^{11}$ By the fall of 1997, the Department had approved more than 160 compacts. ${ }^{12}$ Since 1998, the Department has reviewed more than 500 compacts. ${ }^{13}$ It has disapproved at least 20 and expressed concern about more than 60 , as reflected in "deemed approved" letters. Taken together, the Department's more than 660 decision letters reflect wide contours in gaming compact approvals, and several themes emerge from review of the disapprovals and "deemed approvals."

In reviewing these issues, it is apparent that compact disapprovals can be avoided through thoughtful consideration of federal interests before compacts are finalized. Planning for federal review and approval, however, is easier said than done. Compact negotiations are fluid and organic; new issues can arise in any negotiation. Moreover, federal interpretations of the statutory ${ }^{14}$ and regulatory ${ }^{15}$ requirements have not remained static; they have developed over time. While all of the requirements are at least implicit in the statute and regulations, discretion and nuance play a role in interpretation by the Department. As with any federal agency's work, the contours of the law can be gleaned from past decisions. The purpose of this brief article is to highlight some of the recurring problems that impact compact approval and offer guidance on avoiding terms in tribal-state gaming compacts that can lead to disapproval.

\section{DEPARTMENT OF THE INTERIOR'S AUTHORITY TO DISAPPROVE}

The Department's role in reviewing tribal-state gaming compacts under IGRA is surprisingly broad. IGRA authorizes the Secretary to disapprove a compact if it violates IGRA, if it violates any other federal law, or if it violates the trust obligations of the United States to Indians. ${ }^{16}$ As explained more

${ }^{8}$ Letter from Kevin K. Washburn, Assistant Secretary for Indian Affairs, U.S. Department of the Interior, to Hon. Deval Patrick, Governor of the Commonwealth of Massachusetts (Oct. 12, 2012), 79 Fed. Reg. 6,213 (Feb. 13, 2014), available at $<$ http://www.indianaffairs.gov/cs/groups/webteam/documents/ text/idc1-028222.pdf>.

${ }^{9}$ Letter from Kevin K. Washburn, Assistant Secretary for Indian Affairs, U.S. Department of the Interior, to Hon. Cedric Cromwell, Chairperson Mashpee Wampanoag Tribe (Jan. 6, 2014), available at $<\mathrm{http}: / / \mathrm{www}$. indianaffairs.gov/cs/groups/webteam/ documents/document/idc1-028231.pdf $>$.

${ }^{10}$ Letter from Gale A. Norton, United States Secretary of the Interior, to Hon. Cyrus Schindler, President of the Seneca Nation of Indians (Nov. 12, 2002), available at <http://www.indianaffairs .gov/cs/groups/xoig/documents/text/idc-038394.pdf>.

${ }^{11}$ Lower Sioux Community Reservation Compact with the State of Minnesota, 55 Fed. Reg. 12,292 (Apr. 2, 1990), available at $<$ http://www.indianaffairs.gov/cs/groups/xoig/documents/text/ idc1-025919.pdf>.

${ }^{12}$ Letter from Bruce Babbitt, United States Secretary of the Interior, to the Hon. Wendell Chino, President of the Mescalero Apache Tribe (Aug. 23, 1997), available at <http://www.indian affairs.gov/cs/groups/xoig/documents/text/idc-038382.pdf>.

${ }^{13}$ Archive of Tribal-State Indian Gaming Compacts, DePARTMENT OF THE INTERIOR, OFFICE OF INDIAN AFFAIRS, <http:// www.indianaffairs.gov/WhoWeAre/AS-IA/OIG/Compacts/index .htm/> (last visited Feb. 25, 2016).

${ }^{14}$ See IGRA, 25 U.S.C. $\$ \S 2701-2721$ (2015).

${ }^{15}$ The Department has enacted regulations implementing IGRA. 25 C.F.R. $\S \S 502.21-502.24$ (2015).

${ }^{16} 25$ U.S.C. $\$ 2710(d)(8)(B)$ (2015). The Secretary's regulatory role as to compacts under IGRA is codified at 25 C.F.R $\$ \S$ 293.1-293.16 (2015). 
fully below, the most common basis for disapproval is the first: that is, that the compact is inconsistent with IGRA.

Because it is not easy to articulate comprehensively the precise scope of "trust obligations of the United States to Indians[,]" and perhaps because interpreting the term in this context could have farreaching ramifications in decisions and litigation in other areas, the Department has been reluctant to use the "trust obligation" language as a basis for disapproval. Indeed, it appears that the Department has never used that factor as the sole basis for disapproval. However, it is sometimes mentioned as a source of concern and perhaps a partial basis for disapproval. ${ }^{17}$

\section{DYNAMICS OF NEGOTIATION AND REVIEW}

In the heat of negotiations between a tribe and a state, it is perhaps easy to overlook the Department's role because the Department is not a party and because Washington, D.C., is far away. Parties are likely to focus more on the iterative process of negotiation and the particular political needs of tribal and state political actors, with the agreement developing into a document unique to the needs of the parties. Absent some form of approval, however, a compact is not valid. Thus, it is exceedingly important for the parties to consider the requirements for federal approval during their negotiations.

A complicating factor for Department review is the tight deadline for decision. Under IGRA, Interior has only 45 days to make a decision on a gaming compact once it is submitted for review. ${ }^{18}$ Moreover, the Department's Office of Indian Gaming frequently asks the parties for additional information to help the Department conduct its analysis after the 45-day review period has begun. One proactive step for the parties to consider is jointly requesting a meeting with Department staff before the agreement is finalized or ratified or signed. If the parties brief the Department on the contours of the proposed compact, staff can highlight potential areas of concern. The opportunity for informal guidance from the Department has long been available. In 2002, Secretary Norton implored parties to use this informal process to avoid placing the Department, and the parties, in a tough position. ${ }^{19}$ While the gaming staff at the Department usually will decline to issue any sort of pre-approval in deference to the fact that they are not the final decision makers, the staff can be helpful in highlighting obvious issues for the parties. This process may even be used occasionally as a negotiation tactic. Such a meeting is not only for the benefit of the parties: a meeting can give comfort to the federal staff, who will not have much time to review the compact when it is ultimately submitted.

The most obvious decision options by the Department are approval or disapproval. However, IGRA also provides that a compact not approved within 45 days of receipt by the Department is considered approved, but only to the extent that it is consistent with law. The 45-day provision presumably is a decision-forcing mechanism. However, it has given rise to a curious practice at the Department and effectively created a third path for the Department. It works as follows. Sometimes, the Department declines to issue an approval because of concerns with a compact; however, it also declines to issue an affirmative disapproval. In those instances, the compact is approved by operation of law. Howeverand this is the unusual part - the Department sometimes issues a letter contemporaneously with the expiration of the 45-day period or shortly thereafter, explaining its concerns about the compact. Thus, in practice, the Department has three options when it reviews a gaming compact: approval, disapproval, or "deemed approval" with or without comment.

Why would the Department decline to take affirmative action of either approval or disapproval? As noted above, a compact often reflects the culmination of months or years of negotiation and significant legislative and executive processes within state and tribal sovereign governments. A disapproval is likely

\footnotetext{
${ }^{17}$ See, e.g., Letter from Kevin K. Washburn to Hon. Deval Patrick, supra note 8 (noting that compact provision involving state-tribal agreement to revolve hunting and fishing right "may violate the United States trust obligation to Indians"). $C f$. Letter from Donald Laverdure, Principal Deputy Assistant Secretary for Indian Affairs, U.S. Department of the Interior, to Hon. Kimberly M. Vele, President, Stockbridge-Munsee Community of Mohican Indians (Feb. 11, 2011), available at $<$ www.indianaffairs.gov/cs/groups/xoig/documents/text/idc1024497.pdf $>$ (compact provisions requiring trust lands to be used only for gaming impermissible).

${ }^{18} 25$ U.S.C. $\$ 2710(\mathrm{~d})(8)(\mathrm{c})$. This requirement is codified at 25 C.F.R $\S \S 293.10-293.12$ (2015). It is also important to remember that the Department's time runs not from the time of signing, but from the time it is submitted to the Department's office of Indian Gaming for review. See 25 C.F.R. § 293.9.

${ }^{19}$ Letter from Gale A. Norton to the Hon. Cyrus Schindler, supra note 10, at 2 n.1.
} 
to be a major disappointment to the tribe, which may have developed significant plans and investment around the expectation of an approved compact. The Department generally owes a trust responsibility to tribes, and Department officials understand, better than almost anyone other than tribal leaders themselves, the importance of strong tribal economic development. Often, disapproval may be the best course for national policy, but it is likely to have short-term negative effects for the tribe whose compact was disapproved. Likewise, compact disapproval will likely disappoint the state that has entered the compact, which may be expecting revenue sharing or other benefits through the compact. As a result, the Department is loath to disapprove compacts. Moreover, powerful external political forces are often brought to bear to discourage the Department from issuing disapproval.

On the other hand, there are often items in compacts that give the Department significant concern. While the Department is loath to issue a disapproval, the Department may also wish to avoid providing a stamp of approval to terms in a compact that are problematic or potentially problematic. The "deemed approval" approach allows the parties to move forward with Class III gaming, but it preserves the legal issue for a potential showdown in the courts or an arbitration proceeding at a later date. ${ }^{20}$ As a practical matter, the "deemed approval" approach allows the compact to take effect, but withholds the Department's endorsement of problematic terms.

A "deemed approval" generally occurs in three broad circumstances. First, the terms of concern in a compact may be ambiguous. In that circumstance, the Department can express its views as to the lawful interpretation of the terms and express an expectation that the ambiguous terms will be applied in a lawful manner. ${ }^{21}$

Second, the Department may have concerns about a term, but it may be unlikely that facts making that term material would actually occur in the real world. Thus, the term may be theoretically problematic, but practically irrelevant. For example, a compact may require that a tribe provide the state a revenue share of 25 percent of net gaming revenue above a certain annual threshold, such as $\$ 1$ billion dollars. This percentage might be thought by the Department to be far too high. However, if the gaming operation's annual revenues are currently below $\$ 100$ million, the Department might find that the term is not likely to ever become operable. ${ }^{22}$
Finally, the Department may issue a "deemed approval" if the compact is generally positive for the tribe and it contains only a single serious issue of concern, or a few minor issues. For example, a tribe's new compact, despite the Department's concerns, may objectively be a marked improvement across a wide range of subjects over the tribe's existing compact. In rare cases like this, the Department may issue a "deemed approval" so as not to "let the perfect be the enemy of the good." 23

As the compact approval process has developed, a number of issues have arisen over and over. This article will now turn to the Department's "repeat offenders"- that is, problematic provisions that seem to appear often in compacts submitted to the Department for approval.

\section{REQUIREMENT THAT TERMS IN COMPACTS BE GERMANE TO CLASS III GAMING}

Serious concerns can arise when a compact attempts to resolve matters utterly unrelated to the gaming activity. In general, it is understandable why the temptation exists to address such matters. Tribal and state governments have numerous issues of mutual concern, some of which produce conflict. These include boundary disputes, land rights or claims, hunting and fishing rights, water rights,

\footnotetext{
${ }^{20}$ The complex and time-intensive nature of compact negotiations may also counsel the inclusion of a severability clause that would permit a compact to be approved even if a discrete provision is deemed to violate IGRA. While the Department does not have explicit independent authority to strike offensive provisions and render an affirmative approval, the parties can effectively provide such authority in the terms of the compact. See, e.g., Kialagee Tribal Town Compact with the State of Oklahoma, at $\S 15 \mathrm{D}$ (July 8, 2011), available at $<\mathrm{http}: / / \mathrm{www}$ indianaffairs.gov/cs/groups/xoig/documents/text/idc1-024687.pdf > In the absence of the parties providing this authority, the Department can accomplish a similar result by calling out the troubling provision in a deemed approval letter.

${ }^{21}$ Jicarilla Apache Nation, Deemed Approved Letter, Tribal State Gaming Compact, 80 Fed. Reg. 35,668 (June 22, 2015), available at <http://www.indianaffairs.gov/cs/groups/xoig/documents/ text/idc1-031301.pdf $>$.

${ }^{22}$ Karuk Tribe, Deemed Approved Letter, Tribal State Gaming Compact, 79 Fed. Reg. 68,910 (Nov. 19, 2014), available at $<\mathrm{http}$ //www.indianaffairs.gov/cs/groups/xoig/documents/text/ idc1-028626.pdf >.

${ }^{23}$ Francios Marie Arouet (Voltaire), Dictionnaire PhilosophIQue Portatif (1764), reprinted in Concise OXFord DictionARY OF QuOTaTIONs 797 (Susan Ratcliffe ed., 6th ed., 2011).
} 
and tax disputes, among others. The natural tendency may be to address them along with gaming issues in gaming compact negotiations, especially if those negotiations are proceeding productively. While gaming compact negotiations may provide a convenient opportunity to address such issues, the Department has begun to look much more critically at such provisions when they are found in compacts. For reasons explained more fully below, compact provisions related to non-gaming matters are usually illegal. Thus, states and tribes should be cautious about addressing non-gaming issues within the gaming compact.

In IGRA, Congress carefully created a regulatory scheme with distinct roles for the various sovereign governments involved. Class I gaming is regulated exclusively by Indian tribal governments; Class II gaming is regulated primarily by tribal governments in cooperation with the federal government; and, Class III gaming is regulated primarily by tribal governments and, to the extent negotiated in an approved compact, a state government. In addition to assigning these regulatory opportunities for classes of gaming to specific governments, Congress clearly and explicitly limited the scope of negotiations regarding the gaming compact. ${ }^{24}$ IGRA explicitly identifies six subjects that parties may negotiate, and a seventh subject, the so-called "catchall." The lawful subjects of negotiation include (1) criminal and civil laws "related to, and necessary for" the licensing and regulation of gaming; (2) allocation of jurisdiction necessary to enforce gaming laws; (3) assessments by the state to defray costs of regulating gaming activity; (4) tribal taxation in amounts comparable to state taxation for similar activities; (5) remedies for breach of contract; and (6) standards for the operation of gaming and maintenance of the gaming facility. ${ }^{25}$ The seventh category of proper subjects for negotiation includes "any other subjects that are directly related to the operation of gaming." 26 In sum, Congress mandated that the lawful scope of gaming compacts-and thus, presumably, compact negotiations-be limited to the six matters explicitly named and any other subject "directly related" to gaming.

The basic legal theory for the limitation on subjects addressed in compacts is expressio unius, or for those who appreciate completeness, expressio unius est exclusio alterius. By clearly, thoroughly, and explicitly identifying the subjects that can be addressed in a compact, Congress presumably intended to limit compacts to those subjects. As dis- cussed below, IGRA contains other provisions that support this theory. For example, IGRA requires states to negotiate with tribes in good faith. ${ }^{27}$ The limitation on subject matter gives meaning to what constitutes good faith. Second, Congress carefully limited state authority to issues dealing with Class III gaming and explicitly provided no state role in Class I and II gaming. ${ }^{28}$

Why would Congress limit the subjects to be included in a Class III gaming compact? A clear message that comes through in the legislative history is that Congress sought to prevent a state from using its right to compact negotiation to extend state authority beyond gaming. This would presumably include using that authority to force resolution of other issues, unrelated to gaming. The very real concern is that a state may use its leverage over Class III gaming to exact a favorable resolution of issues unrelated to Class III gaming. ${ }^{29}$ Put more bluntly, because an approved gaming compact is a legal requirement for Class III gaming, a state could withhold negotiation or consent in an effort to address matters not related to gaming, thus holding Indian gaming hostage to other demands.

While the temptation for state negotiators to bootstrap may be high, the actual need for state authority over such matters is low. Across a range of examples, the issues presented simply do not address the unique concerns raised by states related to the risks of gaming. Thus, justification for addressing such matters in a gaming compact is lacking.

Examples of including matters unrelated to gaming abound. In a tribal state compact in Oklahoma, the State of Oklahoma negotiated the right to terminate the gaming compact if there was a material breach by the tribe of the terms of a separate tobacco compact. ${ }^{30}$ In a California gaming compact, the parties sought to create state jurisdiction over food

\footnotetext{
${ }^{24} 25$ U.S.C. $\$ 2710(d)(3)(B)$ and (C)(i)-(vii) (2015).

${ }^{25} 25$ U.S.C. $\$ 2710$ (d)(3)(C)(i)-(vi) (2015).

${ }^{26} 25$ U.S.C. $\$ 2710$ (d)(3)(C)(vii) (2015) (emphasis added).

${ }^{27} 25$ U.S.C. $\$ 2710(\mathrm{~d})(3)(\mathrm{A})$.

${ }^{28}$ Compare 25 U.S.C. $§ 2710$ (a) and (b) with 25 U.S.C. $\S$ $2710(\mathrm{~d})$.

${ }^{29}$ See, e.g., Sen. Rep. No. 100-446 on the Indian Gaming Regulatory Act, to accompany S. 555, at 10, 14, including additional views of Mr. McCain, at 34 (1988).

${ }^{30}$ Letter from Larry Echo Hawk, Assistant Secretary for Indian Affairs, U.S. Department of the Interior, to Hon. Tiger Hobia, Mekko, Kialegee Tribal Town (July 8, 2011), available at $<$ http://www.indianaffairs.gov/cs/groups/xoig/documents/text/ idc1-024687.pdf $>$.
} 
and beverage services at the casino and drinking water quality on the reservation. The Department noted that "the Tribe's provision of food, beverages, and drinking water to its patrons may occur on the same parcel [of land] on which it conducts class III gaming, [but] it does not ... follow that it is "directly related [to gaming] under IGRA." 31 The Department determined that this term was "inconsistent" with IGRA, but avoided disapproval of the agreement; it allowed the compact to be deemed approved.

Another example appeared in the initial Mashpee Wampanoag compact with the Commonwealth of Massachusetts. ${ }^{32}$ In this compact, which was disapproved, the compact listed the governor's and Commonwealth's consideration of the resolution of important issues related to "hunting, fishing, and land use" as part of the exchange that justified state revenue sharing. When pressed, the tribe admitted that it had requested the language "in an effort to resolve longstanding issue between the tribe and the state." The Department's disapproval was clear, however: "the Tribe's hunting and fishing rights cannot be placed upon the bargaining table when it negotiates a [gaming compact]." ${ }^{33}$

These limitations are not of recent vintage. Secretary Norton raised concerns about attempts to address issues not germane to gaming in a 2002 decision letter. ${ }^{34}$ In that case, the State of New York had negotiated a term in the compact that required the Seneca Nation of Indians to use all of its remaining settlement funds for the purposes of housing only. While an objective reading of the provision would suggest that it was an attempt to prevent the tribe from using its settlement funds to purchase additional lands on which it could engage in gaming, the Department criticized the provision. The Department found "tenuous" the tribe's claim that the provision was directly related to gaming because the primary purpose of the provision was to allow the tribe to acquire land next to the gaming facility. Ultimately, despite a number of problems highlighted by Secretary Norton, the compact was deemed approved, leaving the legality of some of the terms for another day.

One might find it curious that, in the Mashpee case, for example, the Department issued the disapproval even though the tribe affirmatively wished to include the non-gaming subject in gaming compact negotiations. From the Department's standpoint, however, IGRA creates a relatively bright line about what can be addressed in a compact and, from a policy point of view, preserving that bright line is important. Otherwise, a tribe might be required to negotiate issues, perhaps even under duress, because the state insisted.

In light of the clear guidance from Congress in IGRA and increasing scrutiny on these issues from Interior, a compact that includes unauthorized subjects may well be disapproved. Thus, the parties negotiating compacts should avoid the inclusion of provisions not directly related to the operation of Class III gaming activities.

\section{REQUIREMENT TO AVOID REGULATING CLASS II GAMING}

Another issue that can arise in compact negotiations is Class II gaming. Some forms of electronic Class II games, played in video gaming cabinets, look similar to Class III slot machines. Such Class II gaming machines are sometimes known as "Class 2.9" games. Despite the colloquial label, such Class II gaming is clearly lawful under IGRA and is legally distinct from Class III gaming. The right of tribes to offer such games was clearly established through extensive litigation that began in the district courts in the 1990s and produced appellate decisions upholding the right in four different circuit courts in the early $2000 \mathrm{~s}^{35}$

\footnotetext{
${ }^{31}$ Letter from Donald E. Laverdure, Acting Assistant Secretary for Indian Affairs, U.S. Department of the Interior, Department of the Interior, to the Hon. Greg Sarris, Chairman, Federated Indians of the Graton Rancheria (July 13, 2012) at 11, available at <http://www.indianaffairs.gov/cs/groups/xoig/documents/ text/idc1-026885.pdf>.

${ }^{32}$ See, e.g., Mashpee Wampanoag Compact with the Commonwealth of Massachusetts (Oct. 12, 2012), available at <http:// www.indianaffairs.gov/cs/groups/webteam/documents/text/ idc1-028222.pdf>.

${ }^{33}$ Letter from Kevin K. Washburn, Supra note 8.

${ }^{34}$ Letter from Gale A. Norton to the Hon. Cyrus Schindler, supra note 10 , at 7 .

${ }^{35}$ See, e.g., Seneca-Cayuga Tribe of Okla. v. Nat'1 Indian Gaming Comm'n, 327 F.3d 1019 (10th Cir. 2003), cert. denied, 540 U.S. 1218 (2004); United States v. Santee Sioux Tribe of Neb., 324 F.3d 607 (8th Cir. 2003), cert. denied, 540 U.S. 1229 (2004); United States v. 162 Mega-Mania Gambling Devices, 231 F.3d 713 (10th Cir. 2000); Diamond Game Enterprises v. Reno, 230 F.3d 365 (D.C. Cir. 2000); United States v. 103 Electronic Gambling Devices, 223 F.3d 1091 (9th Cir. 2000). For more discussion of the broader context, see Kevin K. Washburn, Agency Culture and Conflict: Federal Implementation of the Indian Gaming Regulatory Act by the National Indian Gaming Commission, the Bureau of Indian Affairs, and the Department of Justice, 42 ARIz. ST. L.J. 303 (2010).
} 
The existence of Class II (and Class 2.9) gaming is exceedingly important to tribes for at least two reasons. First, especially in light of the Seminole Tribe ${ }^{36}$ decision, which undermined tribes' ability to sue states for failing to negotiate compacts in good faith, the existence of electronic Class II gaming insures that a tribe can offer some forms of cabinet-based video gaming even in a state that refuses to negotiate a Class III gaming compact. ${ }^{37}$ Second, even for tribes that have approved tribal-state Class III gaming compacts, Class II gaming may be valuable. Class II gaming machines are not subject to limits on the quantity of slot machines, restrictions which exist in some compacts,${ }^{38}$ and the revenues from Class II gaming are not subject to revenue sharing with the state.

For the same reasons that Class II gaming is an important resource for tribes, states may be upset by Class II gaming and sometimes are inclined to seek to address Class II gaming in gaming compacts. For example, in a 2007 compact with the State of Florida, the Seminole Tribe agreed to convert 80 percent of its Class II video bingo terminals to Class III slot machines and further agreed not to lease any new Class II machines, apparently so that the state could be assured of more revenue through its revenue sharing terms. ${ }^{39}$

For a variety of reasons, Class II gaming is not an authorized subject of negotiation for compacts. The context of compact requirements discussed above indicates that the gaming compacts requirement applies only to Class III gaming, not Class II. ${ }^{40}$ Moreover, the regulation of Class II gaming was reserved for tribal and federal regulation. ${ }^{41}$

In part, the tribe's immunity from state involvement in Class II gaming was a political compromise. At the time of the enactment of IGRA in 1988, the Cabazon decision of $1987^{42}$ had clarified that states had very limited jurisdiction over tribal bingo activities. Following Cabazon, tribes seemed to have the unfettered right to engage in bingo, which Congress later classified as Class II gaming, in any state in which bingo was lawful for any purpose. The congressional authors of IGRA presumably hoped for tribal support of its passage. Yet, as a political matter, tribes were highly unlikely to support legislation that rolled back rights that they felt they had already won in Cabazon. As a result, Congress recognized existing gains by tribes and exempted Class II gaming from any compact requirement. ${ }^{43}$

To be sure, the Department has allowed the bright line between state authority over Class II and Class
III gaming to become blurred through rare approvals or "deemed approvals" of gaming compacts containing limitations on Class II gaming. However, the inclusion of such provisions gives rise to the fear that a state government may well have leveraged its congressionally authorized power to negotiate over Class III matters to gain influence over Class II gaming, which is properly beyond state reach. Insuring that negotiations between tribes and states are conducted on a good faith and fair basis is one of the reasons for the Department's approval role. The Department's acquiescence on this issue in rare cases should not be viewed as approval of the inclusion of Class II terms in Class III gaming compacts. The Department has begun to examine these issues much more closely in recent years. As a result, including such provisions in a compact places the compact at risk of disapproval.

\section{AVOIDING STATE EFFORTS TO EXERCISE AUTHORITY OVER ANCILLARY ACTIVITIES AND SPACES}

Another issue that frequently arises is casinorelated, but not gaming-related, amenities. Most gaming operations have additional amenities that

\footnotetext{
${ }^{36}$ Seminole Tribe of Fla. v. Florida, 517 U.S. 44 (1996) (holding that Congress lacks the constitutional authority to abrogate the states' Eleventh Amendment immunity from suits by tribes).

${ }^{37}$ For example, the State of Alabama has refused to negotiate with the Poarch Band of Creek Indians for Class III gaming, but the state's refusal has not prevented the tribe from operating Class II gaming. See Alabama v. PCI Gaming, 801 F.3d 1278 (11th Cir. 2015). See also Connie Baggett, Poarch Creeks Continue Economic Expansion, [Alabama] Press-Register (Feb. 13, 2012), <http://blog.al.com/live/2012/02/poarch_creeks_ continue_economi.html $>$.

${ }^{38}$ Eric J. Swanson, The Reservation Gaming Craze: Casino Gambling Under the Indian Gaming Regulatory Act of 1988. 15 Hamline L. Rev. 471, 482-486 (1992).

${ }^{39}$ Compact Between the Seminole Tribe of Florida and the State of Florida, 73 Fed. Reg. 1,229 (Jan. 7, 2008) (Department declined to approve the Compact affirmatively, but it was deemed approved. A nearly identical term appeared again when a compact returned to the Department in 2010. This compact was affirmatively approved), available at <http://www.indianaffairs .gov/cs/groups/xoig/documents/text/idc1-024674.pdf $>$ (at 24).

${ }^{40}$ See 25 U.S.C. $\$ 2710(\mathrm{~d})(3)(\mathrm{A})(2015)$.

${ }^{41}$ See generally 25 U.S.C. \$ 2710(a) (2015).

${ }^{42}$ California v. Cabazon Band of Mission Indians, 480 U.S. 202 (1987)

${ }^{43}$ Ezekiel J.N. Fletcher, Negotiating Meaningful Concessions from States in Gaming Compacts to Further Tribal Economic Development: Satisfying the "Economic Benefits Test," 54 S.D. L. Rev. 419, 427-432 (2009).
} 
are connected in a business sense to the casino operation and are co-located with a casino, but do not themselves constitute gaming. These range from a simple snack shop, at the modest end, to a full resort with swimming pools, golf courses, hotels, and often multiple restaurants. Such ancillary activities may also include spas, concert venues, conference centers, and even RV parks.

Through the compact process, states have sometimes sought to expand the power that they can exercise over gaming to reach other activities beyond gaming and physical spaces beyond the casino floor. One way this occurs is through exceedingly broad definitions in compacts of the term "gaming facilities" or other definitions of the physical spaces that are subject to state regulation.

State regulation of commercial gaming in the United States and federal regulation governed by IGRA is premised, at least in part, on the notion that gaming activities pose unique risks not presented by golf courses, swimming pools, hotels, restaurants, spas, concert venues, RV parks, or conference centers. At the time IGRA was enacted, gaming was primarily a cash business with a high volume of transactions, sometimes involving large sums of money. ${ }^{44}$ Most of the perceived risks were related to the cashintensive nature of the business, such as theft, corruption, money laundering, and other potential wrongs. Moreover, back then, the industry still had the taint of organized crime. Another risk, unique to gaming, is compulsive or "pathological" gambling.

Like Nevada, Congress adopted a background investigation and personal licensure regime in IGRA for gaming employees. This kind of regime, now used in some manner in every jurisdiction with legalized gaming, involves intrusive background investigations with the level of scrutiny correlated directly to the employee's ability to exploit the casino's vulnerabilities. For example, managers, dealers, and employees who work in the cage or the count room have historically been perceived to present a greater risk to the casino and consequently earn more rigorous scrutiny in background investigations than, for example, food and beverage wait staff, who lack significant access to sensitive areas or resources but are physically located on the gaming floor.

In IGRA, Congress was interested in insuring rigorous regulation in light of the unique risks posed by gaming enterprises. Under general principles of Indian law, states generally lack regulatory authority over ordinary activities conducted by tribes and In- dian people on tribal lands. ${ }^{45}$ Indeed, in some ways, reservations are properly viewed as sanctuaries for tribal governments from state authority. Congress created the compact negotiation process to give a state the opportunity to address its unique and legitimate regulatory concerns about gambling activities that involve state citizens and occur within the boundaries of a state.

The compact process, as noted above, was not created to allow state authorities to encroach on tribal sovereignty as to other subjects that do not pose the unique risks of gaming. If the state lacks authority to regulate a tribal business activity in the absence of a casino, it may not gain authority over such activity by virtue of the tribe's decision to pursue Class III gaming.

Rarely do any of the ancillary activities pose the kind of risks that Congress enabled states to address in Class III gaming compacts. Indeed, while swimming pools pose serious risks to life and health, regulating the risks posed by swimming pools was not what Congress sought to accomplish in IGRA.

The ancillary activities issue has become more salient in recent years, as the Department has repeatedly expressed concerns about the issue. ${ }^{46}$ It has been litigated to a final decision in at least one instance, in a compact arbitration between the State of Arizona and the Pascua Yaqui Tribe. In that case, the state sought to apply its compact regulatory scheme to the tribal hotel, characterizing the hotel as a "gaming facility" because it was physically connected to the casino. The compact gave regulators a virtually unfettered right to enter gaming spaces. The tribe argued, successfully, that such an approach is sensible when regulating gaming spaces, which involve frequent large cash transactions. The tribe argued, however, that this approach was entirely inappropriate as to hotel guest

\footnotetext{
${ }^{44}$ See generally KeVIn K. Washburn, Gaming AND GamBLING LAW: CASES AND Materials 63-124 (Aspen/Wolters Kluwer 2011) (detailing the perceived social harms of gambling which form the bases for regulation of the industry).

${ }^{45}$ Bryan v. Itasca County, Minnesota, 426 U.S. 373, 96 S. Ct. 2102, 48 L. Ed. 2d 710 (1976).

${ }^{46} \mathrm{See}$ Letter from Paula L. Hart, Director, Office of Indian Gaming, to Peter S. Yucupicio, Chairman, Pascua Yaqui Tribe of Arizona (June 2, 2012), available at <http://www.indianaffairs .gov/cs/groups/webteam/documents/text/idc1-028392.pdf>; Letter from Larry Echo Hawk, Assistant Secretary for Indian Affairs, U.S. Department of the Interior, to Leona Williams, Chairperson, Pinoleville Pomo Nation (Feb. 25, 2011), available at $<\mathrm{http}: / / \mathrm{www}$.indianaffairs.gov/cs/groups/xoig/documents/text/ idc1-024673.pdf $>$.
} 
rooms, where patrons have a legitimate right to privacy recognized-and protected - by the Fourth and Fourteenth Amendments to the Constitution. The arbitrators agreed with the tribe, clarifying that the state's gaming regulatory powers do not reach the hotel attached to the casino. ${ }^{47}$

Increasingly, the Department has expressed concern when a compact attempts to sweep ancillary activities or spaces into the realm of state regulation under a gaming compact. Efforts to use a gaming compact to extend state authority over such activities places a compact at risk of disapproval.

\section{CONCLUSION}

The Department is loath to disapprove a tribalstate gaming compact, but it has asserted itself more and more in recent years as issues of concern arise. Because of the difficulty of negotiating (and sometimes ratifying) a compact, state and tribal negotiators should think carefully about the reception the compact will receive at the Department. States and tribes negotiating compacts can avoid significant risk to compact approval by avoiding the common problems mentioned above.

\footnotetext{
${ }^{47} \mathrm{See}$ In the Matter of the Arbitration Between State of Arizona and Pascua Yaqui Tribe (2012) (Gordon, Jones, Bender, Arb.), available at <http://pettibriones.com/wp-content/uploads/2015/ 11/case-arb-award.pdf $>$; Frederick R. Petti, Patricia Lane Briones, Wendell Long, Scope Creep: What Are the Limits Under IGRA on State Powers to Regulate Ancillary Non-Gaming Business Ventures, 18 Gaming L. Rev. And Econ. 19 (2014). See also Letter from Paula L. Hart to Peter S. Yucupicio, supra note 46.
} 